\title{
高クロム不銹鋼の諸性質に及ぼす熱処理の影響
}

\author{
訳 者森岡進 *

\section{Effect of Heat Treatment and Related Factors on Straight- Chromium Stainless Steels}

F. K. Bloom

Corrosion, 9, No. 2, 56 65 (1953) February

序

燒入硬化性のある高 $\mathrm{Cr}$ 不銹鋼は酸性原油,炭酸, 硫黃 を含んだ炭化水素等に対し耐蝕性があるとともに，熱処 理によって硬度や強さを広い範囲にわたって変えること ができるために，製油工業・ガス工業用の部品によく用い られるようになっだ。合金量が比較的低く不銹鋼中最る 安価であることも特徴である。このように用途が堌すと たとえば酸性ガス凝縮井等には新しいタイプの腐蝕を件 らことがわかってきた。その対策はな打研究中であるが，
熱処理が非常に関係することがすでに観察されている。 故に強さや䩓性に対する熱処理の影響と同样に酎蝕性に 対する熱処理の影響にも注意を向けなければならないこ とがわかった。このような理由で高不銹鋼の各檑性質に 対する熱処理の影響について総説することとした。

\section{燒入硬化性高 $\mathrm{Cr}$ 鋸の組成}

この鋼種には第 1 表に示す如く $11 〜 18 \%$ Crを主成分と する 9 整の標準組成があり，炭素量は1.20\%までである。 他の元素 S または Se および Ni を加えたるのるある。

第 1 表 焼入硬化性高 $\mathrm{Cr}$ 不銹鋼の組成

\begin{tabular}{|c|c|c|c|c|c|c|c|c|c|c|}
\hline \multirow{2}{*}{$\begin{array}{l}\text { Tyce } \\
\text { No. }\end{array}$} & \multirow{2}{*}{$\% \mathrm{C}$} & \multirow{2}{*}{$\% \mathrm{Mn}$} & \multirow{2}{*}{$\% \mathrm{P}$} & \multirow{2}{*}{$\% \mathrm{~s}$} & \multirow{2}{*}{$\% \mathrm{Si}$} & \multirow{2}{*}{$\% \mathrm{Cr}$} & \multirow{2}{*}{$\% \mathrm{Ni}$} & \multirow{2}{*}{$\begin{array}{l}\text { 燒入硬华 } \\
\text { 罝度 }{ }^{\circ} \mathrm{F}\end{array}$} & \multicolumn{2}{|c|}{ 最高燒入硬度 } \\
\hline & & & & & & & & & ブリネル & ロツクウエルC \\
\hline 403 & $0.15>$ & $1.09>$ & $0.040>$ & $0.030>$ & $0.50>$ & $11.50 \sim 13.50$ & - & $1700 \sim 1850$ & $380 \sim 315$ & $39 \sim 43$ \\
\hline 410 & $0.15>$ & $1.00>$ & $0.040>$ & $0.030>$ & $1.00>$ & $11.50 \sim 13.50$ & - & $1700 \sim 1850$ & $380 \sim 415$ & $39 \sim 43$ \\
\hline 414 & $0.15>$ & $1.00>$ & $0.040>$ & $0.030>$ & $1.00>$ & $11.50 \sim 13.50$ & $1.25 \sim 2.50$ & $1800 \sim 1950$ & $400 \sim 450$ & $42 \sim 47$ \\
\hline 416 & $0.15>$ & $1.25>$ & $*$ & $*$ & $1.00>$ & $12.00 \sim 14.00$ & - & $1700 \sim 1850$ & $380 \sim 415$ & $39 \sim 43$ \\
\hline 420 & $>0.15$ & $1.00>$ & $0.040>$ & $0.030>$ & $1.00>$ & $12.00 \sim 14.00$ & - & $1800 \sim 1900$ & $530 \sim 560$ & $53 \sim 56$ \\
\hline $420 \mathrm{~F}$ & $>0.15$ & $1.00>$ & * & $*$ & $1.00>$ & $12.00 \sim 14.00$ & - & $1800 \sim 1900$ & $530 \sim 560$ & $53 \sim 56$ \\
\hline 431 & $0.20>$ & $1.00>$ & $0.040>$ & $0.030>$ & $1.00>$ & $15.00 \sim 17.00$ & $1.25 \sim 2.50$ & $1800 \sim 1950$ & $410 \sim 440$ & $42 \sim 46$ \\
\hline $440 \mathrm{~A}$ & $0.60 \sim 0.75$ & $1.00>$ & $0.049>$ & $0.030>$ & $1.00>$ & $16.00 \sim 18.00$ & - & $1850 \sim 1950$ & $555 \sim 590$ & $55 \sim 58$ \\
\hline $440 \mathrm{~B}$ & $0.75 \sim 0.95$ & $1.00>$ & $00.40>$ & $0.030>$ & $1.00>$ & $16.00 \sim 18.00$ & - & $1850 \sim 1950$ & $575 \sim 610$ & $57 \sim 59$ \\
\hline $440 \mathrm{C}$ & $0.95 \sim 1.20$ & $1.00>$ & $0.040>$ & $0.030>$ & $1.00>$ & $16.00 \sim 18.00$ & - & $1850 \sim 1950$ & $620 \sim 630$ & $60 \sim 62$ \\
\hline $440 \mathrm{~F}$ & $0.95 \sim 1.20$ & $1.00>$ & * & $*$ & $1.00>$ & $16.00 \sim 18.09$ & - & $1850 \sim 1950$ & $620 \sim 630$ & $60 \sim 62$ \\
\hline
\end{tabular}

* $\left\{\begin{array}{c}\mathrm{P}, \mathrm{S} \text { または } \mathrm{Se} \geq 0.07 \% \\ \mathrm{Zr} \text { または } \mathrm{Mo}<0.60 \%\end{array}\right.$

すべて㮱入硬化性があり，最高焼入硬度は炭素量によっ て異なる。焼入組織がマルテンサイトであるからマルテ ンサイト鐝ともいう。各鋼の発展の理由を簡単に述べる と次の如くである。先祖は Type 420 鋼でこれは英国で 多物用として発展した最初の不銹鋼である。約 $0.3 \% \mathrm{C}$ と $13 \% \mathrm{Cr}$ を含み高温鍛練が容易で，また家庭用ナイフ に充分な硬度を与えることができ，この状態で食料品に よる侵蝕に耐える。しかしながらこの初期の不銹鋼は焼 戻したり軟化したりすると耐蝕性が著しく減ずるから充
分焼入硬化した状態でしか用いることができず，用途が 非常に制限されていた。炭素量を下げれば有用性が増す ことがわかり，現在の Type 410 鋼が生れた。この鋼は 焼戾または焼鈍によって硬度をいろいろに変えることが できる。さらにSまたはSeを加えると切侩性が改良さ れることがわかり, Type 416 と $420 \mathrm{~F}$ の、2種の鋼が造ら れた。Type 403 鋼はタービン翼打よび応力の強くかか る部分に適するるのとして, Type 410 鋼の特別品質の よいるのを必要とすることから造られた鋼である。Type

* 東北大学工学部金属工学科 
$440 \mathrm{~A} ， 440 \mathrm{~B} ， 440 \mathrm{C}$ よび440 Fの各鋼は工具鋼に匹敵 する硬度を持った耐蝕耐磨耗用鋼の要求から発達した。 屍素量によって硬度と靯性が少しつつ違う。Type 414鋼 は Type 410 に約 $1.5 \% \mathrm{Ni}$ を加え, Type 431 鋼は Cr量 を増すとともに約 $1.5 \% \mathrm{Ni}$ を加えて，耐蝕性を増した もので, 後者は焼入硬化性, 不锈鋼中合金量が最も高く, 最近の析出硬化性不锈鋼が出現するまでは硬化性不銹鋼 のうちで最も耐蝕性が大であった。

\section{熱処理一般}

高 $\mathrm{Cr}$ 鋼の熱処理性を一般的に述べると炭素䟖と同様 であって，高温に加熱急冷すれば硬化し，これを低温ま たは高温に加熱することによりいろいろの程度に軟化す ることができる。軟化焼鈍の場合は変態温度のすぐ下ま で加熱し, 完全焼䤠の場合には変態温度の少し上まで加 熱して徐冷する。

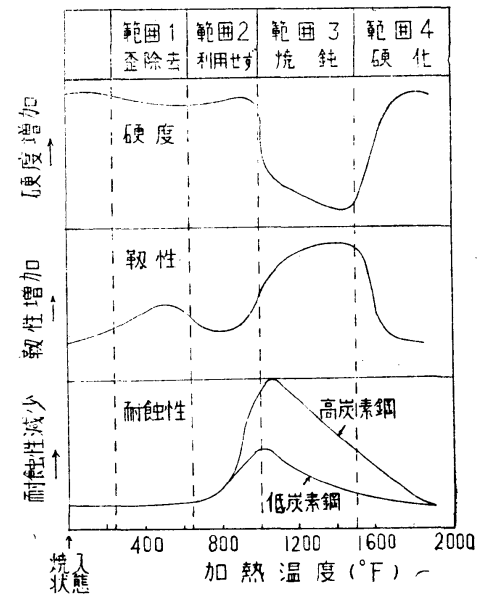

\section{第 1 図 焼入硬化した高 $\mathrm{Cr}$ 不銹鋼の諸性質 に及ぼす加熱温度の影響}

第 1 図は焼入材を各温度に加熱したときの諸性質の変 化の一般的傾向を示したるのである。焼入硬化性不銹鋼 はみなこのような特性を示す。

最初の焼入硬化状態においては各鋼ともマルテンサイ 卜組織であって，孷素量が高いほど硬く靶性が少ない。 その耐蝕性は二三の例外を除いては焼戾したものよりる 優れている。組織が均一でありかつ $\mathrm{Cr}$ の最大量が $\mathrm{Fe}$ 中に固溶して耐蝕性に与かっているからである。Type 4 10あるいは 416 鋼のよ5な低炭素鋼では焼入組織中に非 常に少量のbフェライトを含むかもしれないが，硬度を 少し低くする以外にはあまり影響がない。屍素量が約0. $25 \% \mathrm{C}$ 以上の鋼ではマルテンサイト組織中に $\mathrm{Fe}-\mathrm{Cr}$ 宸化 物を含み,炭化物中の Cr 量は多いから,Type 440A〜 F .のよ5な鋼では $\mathrm{Cr}$ 量を多くして，基地の固溶体中の $\mathrm{Cr}$

为十予第く保たせる。炭化物は非常に硬くかつ耐蝕性で
鋼の硬度と耐磨耗性に役立つ。なお易倠性不銹鋼では組 織中に非金属性の硫化物またはセレン化物を含んでいる。 この粒子は高温で非常に軟かく，高温加工すればよく延 びて鋼に緎維状組織を与え, 鞄性と耐蝕性を減ずるが, 機械切削性を非常に助ける1)。

加熱による諸性質の变化を説明するには加熱温度を 4 つの範团沉分けると便利である。

範囲1. 歪除去一含 $\mathrm{Cr}$ マルテンサイトを約 400 ～700 $\mathrm{F}$ (150〜 $\left.370^{\circ} \mathrm{C}\right)$ の範囲で加熱すると焼入操作によって 生じた内部歪が一部除かれ，硬度をわずかに減じ，靫性 を増す。Crは固溶体のままであるから耐蝕性は变らな い。組織の変化はない。

範囲2. 実用せず一約 $700 \sim 1000^{\circ} \mathrm{F}\left(370 \sim 540^{\circ} \mathrm{C}\right)$ の間では有書な組織変化が起るから,この範囲の加熱は 実用しない。まず二次硬化が観察され，これは約 $950^{\circ} \mathrm{F}$ で極大になり，勒性を著しく減ずる。高㞸素の鋼ほどこ れが著しい。約 $0.15 \% \mathrm{C}$ 上上の鋼ではこの範囲の高温 側あるいはそれを少し超えたところで耐蝕性が著しく悪 くなって用いられなくなる。この靯性および耐蝕性の著 しく減ずる原因は次のよ5な著しい組織変化がこの範囲 では起るからである2)。すなわちこの範囲の低温側で はマルテンサイトが $\propto$ フェライトと超顕微鏡的な鉄孷化 物粒子とに分解し, 高温側では鉄㞸化物と基地の $\mathrm{Fe}-\mathrm{Cr}$ 固溶体とか反応して Fe-Cr の複炭化物を造る。そして 各宸化物のすぐ近くでは基地の Cr が著しく減じ著しい 不均一を生ずるために耐蝕性を減ずる。

高宸素および $\mathrm{Ni}$ を含も鋼では焼入れたマルテンサイ ト組織中には少量の残留オーステナイトを含さが, これ をこの温度範囲で加熱すると, 残留オーステナイトが分 解して新しいマルテンサイトを生ずる。これる二次硬化 扣よび靶性の減少に与かる。Type 431 鋼は特にこの特 性を生じ易く, 機械的性質は焼入温度に, ひいては残留 オーステナイトの量に著しく影響される。

範囲3. 燒戻および焼鍍一 $1000^{\circ} \mathrm{F}\left(540^{\circ} \mathrm{C}\right)$ と変態温 度までの温度範国では $\mathrm{Cr}$ 宸化物が漸次凝集し顕微鏡的 に見得るようになる。孷化物粒が大きくなるとともに硬 度は急に落ち, 変態点直下の燒鈍範囲で極小に達する。 靱性は急に増し，耐蝕性は漸次改良される。一般に狫入 および歪除去状態に拉けるほど耐蝕性はよくないが，低 崖素鋼ならば比較的よくて実用し得る。しかし高㞸素鋼 では耐蝕性の回復が少なく，実用できない。

この温度範囲では Cr が基地を抎散し，Cr炭化物附近 の $\mathrm{Cr}$ 欠乏部へ $\mathrm{Cr}$ の補充が行われる。0.1\% C，12.5\% Crを含む鋼の場合には宸素の全部が炭化物になってる，

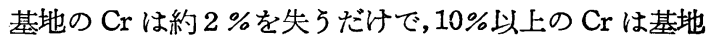
に均一に分布し耐蝕性は充分である。ところが $0.3 \% \mathrm{C}$ ， $1.3 \% \mathrm{Cr}$ を含むType420の如き鋼では炭化物形成のため 
に約 $6 \% \mathrm{Cr}$ が失われるので, 基地の $\mathrm{Cr}$ 含量は著しく減 じ，耐蝕性不十分になる。これが前述のよ5な差を生ぜ しめる原因である。

な敃第1図に示してあるようにどの銅でも変態点は大 体 $1475^{\circ} \mathrm{F}\left(800^{\circ} \mathrm{C}\right)$ である。ただし Ni を含む Type 414 と 431 鋼では約 $200^{\circ} \mathrm{F}\left(110^{\circ} \mathrm{C}\right)$ 低い。

範四4. 硬化一加熱温度が变態点をこえると著しく徐 冷しないかぎり再び焼きが入り，温度上昇とともに焼入 硬度を増し，鋼種により $1700 \sim 1950^{\circ} \mathrm{F}\left(926 \sim 1065^{\circ} \mathrm{C}\right)$ の間で極大に達する。最高硬度の得られる焼入温度は第 1 表に示してある。それ以下の温度から焼入れることを 部分硬化 (Partial hardening)* または半硬化 (Semihardening)* といい, これは Type 410 と 416 鋼には 特別の理由で行うことがあるが，一般には利益がないか ら行わない。

もし急冷する代りにこの温度範囲から $1000^{\circ} \mathrm{F}\left(538^{\circ}\right)$ まで徐冷 ( 1 時間に $50^{\circ} \mathrm{F}\left(28^{\circ} \mathrm{C}\right)$ またはそれ上下) す ると球状炎化物を含んだフェライト組織が得られる。硬 度は最も低い。耐蝕性は低炭素鋼では変態点以下の焼鈍 で得られる組織の耐蝕性とほぼ同じである。高炭素鋼で はこの組織は耐蝕性に有害で実用にならない。

\section{各銅種別熱処理の影望}

\section{Type 403, 410 および 416}

璣械的性啠：加熱温度の影響を第 2 図に示す。図に示 乙てある通り $1400^{\circ} \mathrm{F}\left(760^{\circ} \mathrm{C}\right)$ までは焼戾温度に 4 時間

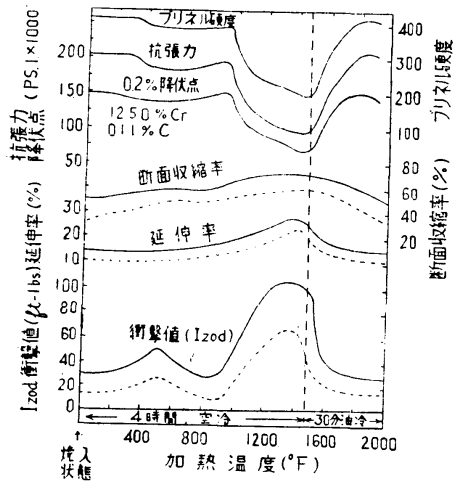

苐 2 図 高 $\mathrm{Cr}$ 不銹鋼Type 403,410, 416 の機械的性質に及更守 加熱温度の影響
保っている。 $800^{\circ} \mathrm{F}\left(427^{\circ}\right.$

C) 以下では 焼杘時間は硬 度にあまり影 響しないがこ れ以上の温度 では時間を増 すとともに硬 度は著しく減 ずる。時間と 温度の影響は 互に関係し
$\mathrm{T}(20+\log \mathrm{t})$ の形のパラメーターで表わされる 3$) 。$ ここに $\mathrm{T}$ は焼杘温度 (絶対温度), $\mathrm{t}$ は時間 (時) であ る。第 3 図は硬度対焼戻パラメーターの曲線, 第 4 図は 時間と温度の任意の組合せに対するパラメーターの值を 求める図である。これ等の曲線から任意の硬度を得るた めの焼戻処理条件を知ることがでさる。例えばブリネル 硬度 240 を望むなら第 3 図からパラメーターは 34200

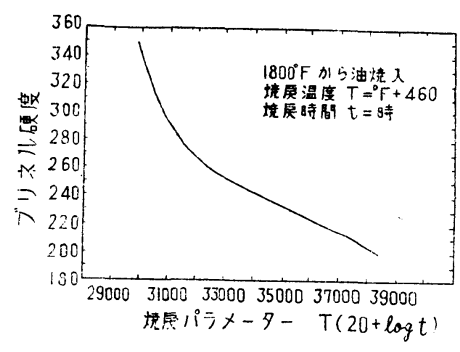

第 3 図 高 $\mathrm{Cr}$ 不銹鋼Type 403,410,416 の焼 杘硬度曲線

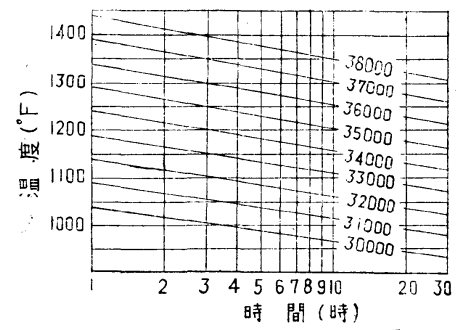

第 4 図 焼杘パラメーターに対する焼戻温度 と時閒の組合せを与える図

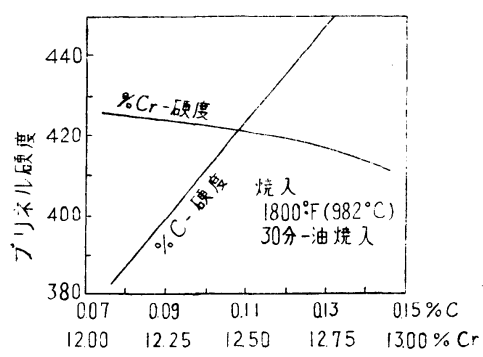

第 5 図 高 $\mathrm{Cr}$ 不銹鋼 Type 403,410,416の焼 入硬度に及ぼす宸素量就よび Cr 量の影響

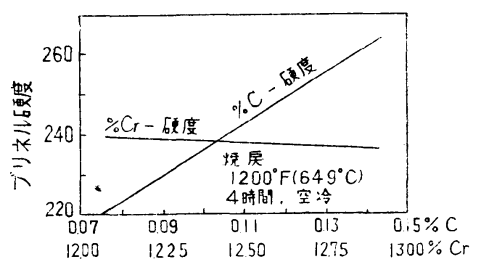

第 6 図 高 $\mathrm{Cr}$ 不銹鋼 Type 403,410,416の焼戻硬 度に改ぼす孷素量拉よびCrの量の影響

* 訳者注；著者のいう意味てこういう術語を用いることは一般的でない。 


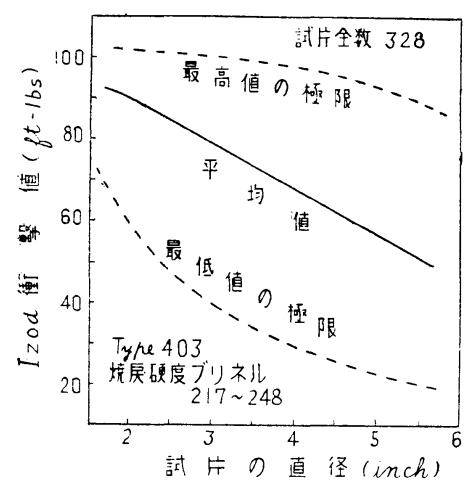

第 7 図 Type 403 鋼焼戻材の Izod 衝撃值 に攻ぼす試片の大きさの影響

になる。第4 図から 34200 に対し $1250^{\circ} \mathrm{F}\left(677^{\circ} \mathrm{C}\right)$ で 1 時間, $1200^{\circ} \mathrm{F}\left(649^{\circ} \mathrm{C}\right)$ で 4 時間, $1150^{\circ} \mathrm{F}\left(621^{\circ} \mathrm{C}\right)$ で 15時間等の值が得られるから，これらのどれかの焼㞔条 件によって要求する硬度が得られる。

ただし第 2 図と第 3 図は最初の焼入硬度ブリネル 418 の材料に対灾する図である。焼入硬度は炭素量および $\mathrm{Cr}$ 量によって変るから素材ごとに少し違うものである。

第 5 図, 第 6 図に崖素量技よび $\mathrm{Cr}$ 量が違了と最初の焼 入硬度および $1200^{\circ} \mathrm{F}\left(649^{\circ} \mathrm{C}\right)$ 焼戻硬度がどれ位違 5 かを示した。最初の焼入硬度の高い素材は焼戻後も高い 硬度を示し，低い素材は軟かい。故に硬度の制限が狹い 場命には予備試験を行って正確な焼戻温度を知ることが 望ましい。扮扣上その䓵戻処理条件を選ら゙にはこれらの 各図が役立ち，これから二，三の予備試験を行って容易 に正確な条件を知ることができる。

この程鋼の熱処理で衝撃虍性がしばしば問題となるが， 䩓性には試片の寸法が影響することがあまり注意されて いない。断面が增すと衝揧性は低く出るもので第 7 図に 示す如くである。

この程鋼の或る用途にはブリネル 260〜320 の範国の 硬度が要求される。この硬度は 2 䅡の異なった熱処理で 得られる。1つは普通の焼戻で十分焼入硬化後約 $1000^{\circ}$ $\mathrm{F}\left(538^{\circ} \mathrm{C}\right)$ 亿焼㞔す方法である。第 2 四に見る如く温度 が少し高くなりすぎると硬度が急に落ちるから, 焼戻温 度と時間を非常によく調節しなければならない。いま 1 つは半硬化すなわら变態点の少し上から焼入れる方法で マルテンサイトとフェライトと炭化物の細かく分散した 組織が得られる。温度調節は上ほど閔密でなくてよい。 このような熱処理をした材料は等入爅戻材より一般に切 削性がよい。機械的性質は第 2 表に示すよ5に衝揧值が 少し劣るだけで，その他は燒戻材と同じである。この種 熱処理を少し改良した方法が特許になっている 5)。バ
ルブ軸等にこの半硬化法が利用されている。

第 2 表 Type 410 鋼の焼入焼戾材と半硬化材と の機械的性質と耐蝕性の比較。

\begin{tabular}{|c|c|c|}
\hline & 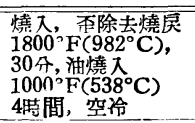 & 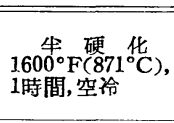 \\
\hline \multicolumn{3}{|l|}{ A. 機械的性筫 } \\
\hline 抗張力 psi & 155000 & 145000 \\
\hline 降伏点 $(0.2 \%) \mathrm{psi}$ & 130000 & 120000 \\
\hline 延伸䇣 \% & 17.0 & 15.0 \\
\hline 䉼面収縮䏬 ％ & 64.0 & 45.0 \\
\hline $1 z o d$ 衝繋值 $\mathrm{ft}-\mathrm{lb}$ & $51-67$ & $19 \sim 28$ \\
\hline ブリネル硬度 & 311 & 298 \\
\hline $\begin{array}{l}\text { B. 酎鳋性 } \\
\quad 2.5 \% \text { 测腾碓酸 }\end{array}$ & \multicolumn{2}{|c|}{ （庥赨度：侵蝕梁さ in/month) } \\
\hline $3 \times 48$ 㭙間 & 0.0924 & 0.0512 \\
\hline \multicolumn{3}{|l|}{ 10\%副腾酔酸 } \\
\hline $1 \times 50$ 時間 & 0.2772 & 0.0262 \\
\hline \multicolumn{3}{|l|}{$2 \%, 120^{\circ} \mathrm{F}$ 硫酸 } \\
\hline $3 \times 4$ 路間 & 0.6314 & 0.3445 \\
\hline
\end{tabular}

耐保性：第 8 图に Type 410 鋼の耐蝕性と焼戻温度の 関係を示す。どの腐蝕作用に対しても焼入硬化および歪 除去の状態が最も吥蝕性が優れ，800～1000 F (427〜 $538^{\circ} \mathrm{C}$ ）で急に悪くなり，それ以上の温度で再び耐蝕性 を增す。腐蝕度の差は最高と最低で 3 倍しか違わない場 合もあり，40倍も違了場合もあり，腐蝕夜によって著し い差がある。食塩水噴奦による腐蝕は主として点蝕であ

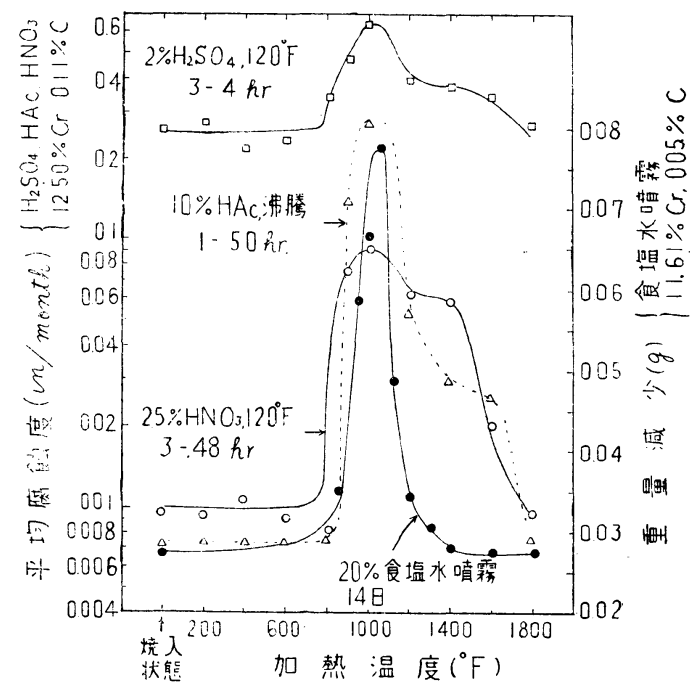

第 8 図 Type 410 鋼の耐蝕性に及ぼす加熱温. 度の影響 


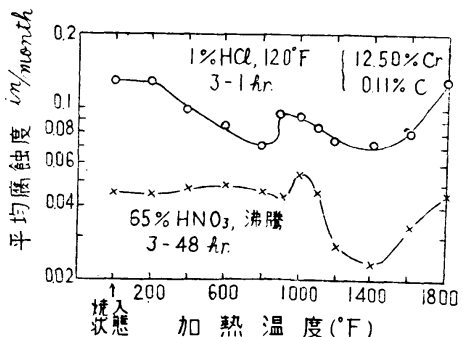

第 9 図 Type 410 鋼の稀薄睢酸および $65 \%$ 硝酸中にお汁る腐蝕度に及ぼす加熱 温度の影響

る。例外は第 9 図に示す沸瞗- $65 \% \mathrm{HNO}_{3}$ と $120^{\circ} \mathrm{F}-1 \%$ $\mathrm{HCl}$ の作用で $1400^{\circ} \mathrm{F}\left(760^{\circ} \mathrm{C}\right)$ 焼鈍材の方が焼入歪除去 材より腐蝕度が少ない。この結果は簡単に説明し難い。 沸騰- $65 \% \mathrm{HNO}_{3}$ 試験はオーステナイト不銹鋼に対する 熱処理效果を決定するのに広く用いられているが，以上 のように焼入硬化性高 $\mathrm{Cr}$ 不銹鋼に同じ目的で適用する と全く誤った結果を得ることになる。

半硬化材料の耐蝕性は第 2 表に示すと挔り普通の焼戻 材の耐蝕性より少しよい。

全面腐蝕や点蝕と異なった機構による腐蝕で“sulfide corrosion cracking”（硫化水素葛蝕割れ）と呼ばれる夕 イプの㢏蝕があり, 最近数馧の報告が出ている。Fraser と Treseder6) は Type 410 鋼のロックウェル硬度 C 28 を示す鍛鍊材は硫化水素脆化を受け易いが，鋳物の焼鈍 材はよく耐えることを報告した。NACE Technical Practices Committee 1-G7) の報告も $12 \% \mathrm{Cr}$ 鋼でロックウ ェル磼度 C 33 を示す鍛鍊材は脆化するが,軟か心鋳造材 は脆化しないことを述べている。 Prange8) は $1700^{\circ} \mathrm{F}$ $\left(927^{\circ} \mathrm{C}\right)$ から焼入れし $1050^{\circ} \mathrm{F} \quad\left(566^{\circ} \mathrm{C}\right), \quad 1120^{\circ} \mathrm{F}$

$\left(604^{\circ} \mathrm{C}\right)$ 扣よび $1200 \mathrm{~F}\left(649^{\circ} \mathrm{C}\right)$ で延伸して陰極的酸 洗をした試料の結果を報告している。焼入れたままの試 料および $1050^{\circ} \mathrm{F}$ で延伸したものは脆化したが, $1120^{\circ} \mathrm{F}$ で延伸した材料は非常にわずか侵されただけであり， $1200^{\circ} \mathrm{F}$ で延伸した材料は脆化しなかった。

も乙硫化水素腐蝕割れが材料の水素脆性への敏感性と 関係するものであるならば，これらの結果は別に鳘くべ きことではない。焼入硬化性のある不銹鋼は焼入組織中 に水素が入ると脆化することがすでに証明されているか らである。同じ材料を焼鈍すると脆化しないことは大变 興味のあることである。Zapffe と Specht9) は Type 410, 431 および $440 \mathrm{C}$ の針金試料について $10 \% \mathrm{NaOH}$ 中で陰 極処理をした後曲げ試験を行ったが，その二，三の結果 は第 3 表に示す如く上記の事夷を非常に明らかに証明し ている。

マルテンサイト組織が水素脆性の傾向を持つことは
第 3 表 水素脆性への敏感性に及方す熱好理の影響

\begin{tabular}{|c|c|c|c|c|}
\hline \multirow{2}{*}{ 鍓 種 } & \multirow{2}{*}{ 状 } & \multirow{2}{*}{ 処理 盢 度 } & \multicolumn{2}{|c|}{$\begin{array}{c}\text { 曲げ試 駧 } \\
\text { 割れ目の生すす度 }\end{array}$} \\
\hline & & & 处理 前 & $\begin{array}{l}\text { 陰極的* } \\
\text { 处理後 }\end{array}$ \\
\hline \multirow[t]{2}{*}{410} & 燒 鈍 & $1400^{\circ} \mathrm{F}\left(760^{\circ} \mathrm{C}\right)$ & $180^{\prime}$ 良 & $180^{\circ}$ 良 \\
\hline & 硬化後雨除去 & $\begin{array}{l}1800^{\circ} \mathrm{F}+730^{\circ} \mathrm{F} \\
\left(982^{\circ} \mathrm{C}+388^{\circ} \mathrm{C}\right)\end{array}$ & $180^{\circ}$ 良 & $40^{\circ}$ \\
\hline \multirow[t]{2}{*}{431} & 燒 鈍 & $1225^{\circ} \mathrm{F}\left(663^{\circ} \mathrm{C}\right)$ & $180^{\circ}$ 既 & $180^{\circ}$ 良 \\
\hline & 硬化後查除去 & $2000^{\circ} \mathrm{F}\left(1093^{\circ} \mathrm{C}\right)$ & $180^{\circ}$ 良 & $31^{\circ}$ \\
\hline \multirow[t]{2}{*}{$440 \mathrm{C}$} & 燒 釛 & $1650^{\circ} \mathrm{F}\left(899^{\circ} \mathrm{C}\right)$ 徐冷 & $180^{\circ}$ 良 & $110^{\circ}$ \\
\hline & 硬化後丕除去 & $\begin{array}{l}1950^{\circ} \mathrm{F}+500^{\circ} \mathrm{F} \\
\left(1066^{\circ} \mathrm{C}+260^{\circ} \mathrm{C}\right)\end{array}$ & $40^{\circ}$ & $20^{\circ}$ \\
\hline
\end{tabular}

* 直徑 0.06 " の針金試片, $10 \% \mathrm{NaOH}$ 溶液中て $1 \mathrm{~A} / \mathrm{in}^{2}$ の電流 密度て 60 分間陰極的に処理し水素索析出させる

$\mathrm{Cr}$ 鋼に限らないで，高抗張力鋼の特性であるようにみ える。特別興味ある問題は，それではどれ位の強さであ れば脆化の恐れなく完全に用い得るかということである が,これについては目下研究中で間もなく明らかになる であろう。

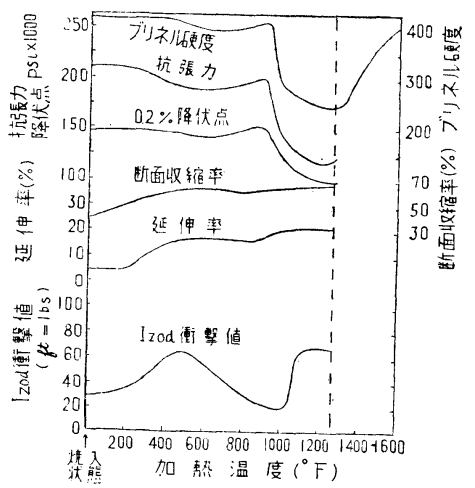

第 10 図 Type 414 鋼の機械的性質に及ぼす 加熱温度の影響

Type 414 および 431

機械的性啠：第10図に新性質に及注す焼㞍温度の影響 を示す。 Ni を含むため焼入温度を高くするとかなり残 留オーステナイトを含む。このオーステナイトは低温で 延伸したときはそのまま含まれていて靱性を增すが高温 で延伸するとその温度から冷却の途中で分解して新しい マルテンサイトを生じて靶性を減ずる。したがって範国 4 (硬化) の高温側で加熱すると最高硬度を生じ, 次に 歪除去をすると最高靱性を生ずる。ところが低温側では 烧杘してすぐ急冷すると最高鞋性を生ずる。

両鋼程とも $1250 \sim 1300^{\circ} \mathrm{F}\left(677 \sim 704^{\circ} \mathrm{C}\right)$ 以上に加熱 すると再び焼きが入り始める。したがってこれ以上の温 度で焼杘しブリネル硬度約 250 以下に軟化することはで きない。また Niを含んでいるとオーステナイトーフェ ライト変態を非常に遲くするから, 変態点以上からの除 冷による完全焼鈍も行えない。 
耐 触 性：熱処理による耐蝕性の変化は前項の Type 403，410 鋼等と同様であるが， Ni を含むため府蝕量は それらより少なく，第 4 表に比較して示すと拈りである。 多くの應蝕作用に対し焼入就よび歪除去の状態が最も耐
えるが，第 3 表の Zapffe のデータによると水素脆性を 生じ易い条件のるとでは逆であって，焼鈍組織が最も耐 える。

第 4 表 Type 410 和よび Type 431 鋼の焼入一歪除去材と焼入焙戻材との耐蝕性比較試験

\begin{tabular}{|c|c|c|c|c|c|c|c|}
\hline \multirow[t]{2}{*}{ 䉞 } & \multirow{2}{*}{ 鳋 } & \multirow{2}{*}{ 試 } & \multirow[t]{2}{*}{ 験 } & \multicolumn{4}{|c|}{ 笍蝕度：侵強深さ in/month } \\
\hline & & & & \multicolumn{2}{|c|}{$\begin{array}{c}\text { Type } 410 \\
1800^{\circ} \mathrm{F} \text { 油燒入 }\left(982^{\circ} \mathrm{C}\right)\end{array}$} & \multicolumn{2}{|c|}{$1900^{\circ} \mathrm{F} \quad \begin{array}{l}\text { Type } \\
\text { 油覝入 }\end{array}$} \\
\hline 简蝕 液 & 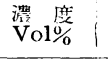 & 盢 & 試 驗 特 間 & $\begin{array}{c}400^{\circ} \mathrm{F} \text { 甭除去 } \\
\left(204^{\circ} \mathrm{C}\right)\end{array}$ & $\begin{array}{c}1200^{\circ} \mathrm{F} \text { 燒扊 } \\
\left(649^{\circ} \mathrm{C}\right)\end{array}$ & $\begin{array}{c}500^{\circ} \mathrm{F} \text { 奀除去 } \\
\left(260^{\circ} \mathrm{C}\right)\end{array}$ & $\begin{array}{c}1150^{\circ} \mathrm{F} \text { 燒晃 } \\
\left(621^{\circ} \mathrm{C}\right)\end{array}$ \\
\hline $\mathrm{H}_{2} \mathrm{SO}_{4}$ & 2.0 & $120^{\circ} \mathrm{F}\left(49^{\circ} \mathrm{C}\right)$ & $3 \times 4$ 陵間 & 0.273 & 0.542 & 0.160 & 0.168 \\
\hline $\mathrm{HCl}$ & 0.25 & $95^{\circ} \mathrm{F}\left(35^{\circ} \mathrm{C}\right)$ & $5 \times 48$ 封間 & 0.045 & - & 0.0002 & - \\
\hline 醋 酸 & 10.0 & 排 蹽 & $1 \times 50$ 時間 & 0.0006 & 0.031 & 0 & 0.0003 \\
\hline 䗃 酸 & 1.0 & $95^{\circ} \mathrm{F}\left(35^{\circ} \mathrm{C}\right)$ & $5 \times 48$ 时間 & 0.0019 & - & 0.0002 & - \\
\hline
\end{tabular}

$\mathrm{Ni}$ を含んでいるため塩化物を含む溶液の作用にも耐 える。ことに Type 431 鋼は塩化物溶液中で繰返し応力 と腐蝕作用とが同時㳊用する応力腐蝕に異常に耐える。 Gough と Sopwith ${ }^{10)}$ が $3 \%$ 食塩水噴霧によって行った 腐蝕疲労試験によると炭素鋼より著しく優れ，15\% Cr 鋼より優れ，低温加工した $18 \mathrm{Cr}-8 \mathrm{Ni}$ 鋼の疲労限に近 い。その結果の一例を第 5 表に示す。

第 5 表 Type 431 鋼の腐蝕疲学強度（繰り返し 曲げ試験） $0.5 \%$ 岸素鋼，15\% Cr鋼特よび $18 \mathrm{Cr}$ $-8 \mathrm{Ni}$ 鋼との比較

\begin{tabular}{|c|c|c|c|c|c|c|c|}
\hline \multirow{2}{*}{ 龂 種 } & \multirow{2}{*}{ C } & \multirow{2}{*}{$\mathrm{Cr}$} & \multirow{2}{*}{$\mathrm{Ni}$} & \multirow{2}{*}{ 状 } & \multirow{2}{*}{ 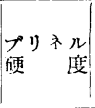 } & \multicolumn{2}{|c|}{ 疲喾 7 强店 } \\
\hline & & & & & & 空気中 & 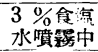 \\
\hline $0.5 \% \mathrm{C}$ & 0.48 & - & - & 常溫殴延 & $280-301$ & $\begin{array}{r}\mathrm{psi} \\
55400\end{array}$ & $\begin{array}{c}\mathrm{psi} \\
11200\end{array}$ \\
\hline $15 \% \mathrm{Cr}$ & 0.12 & 14.75 & - & 燒入燒杘 & $218-221$ & 55400 & 25100 \\
\hline 431 & 0.25 & 17.10 & 1.16 & 燒入燒尼 & $274-384$ & 73300 & 33600 \\
\hline $18-8$ & 0.11 & 18.32 & 8.23 & 常溫匠延 & $242-255$ & 53200 & 39200 \\
\hline
\end{tabular}

Type 420, 420F, 440A, B, C および F

機械的性梊：前に述べた理由からこれら鋼種は燒入招 よび歪除去の状態でだけ用いられる。耐蝕性はいずれる 同じくらいで，ただ硬度と勒性の要求に応じてこれらの 万ち適当な鋼種を選ぶ。最高の勒性を得るための安全な 歪除去温度は約 $500^{\circ} \mathrm{F}\left(260^{\circ} \mathrm{C}\right)$ である。そのときの性

第 6 表 Type 420,440A, B, C 各鋼の烓入歪除 去材の機械的性質（直径 1 "丸棒の平均の性質）

\begin{tabular}{|c|c|c|c|c|c|c|c|}
\hline \multirow{2}{*}{ 鐝種 } & 硬 度 & 範 囲 & \multirow[b]{2}{*}{$\begin{array}{c}\text { 抗 張 力 } \\
\text { psi }\end{array}$} & \multirow{2}{*}{$\begin{array}{c}0.2 \% \\
\begin{array}{c}2 \\
\text { 降点 } \\
\text { psi }\end{array}\end{array}$} & \multirow{2}{*}{\begin{tabular}{|c} 
延伸亲 \\
$\%$
\end{tabular}} & \multirow{2}{*}{$\begin{array}{c}\text { 糟面 } \\
\% \\
\%\end{array}$} & \multirow{2}{*}{ 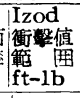 } \\
\hline & プリネル & $\begin{array}{l}\text { ロツク } \\
\text { ウエル }\end{array}$ & & & & & \\
\hline 420 & $470-530$ & C48-53 & 230000 & 195000 & 8 & 25 & $5-15$ \\
\hline $440 \mathrm{~A}$ & $490-530$ & C $49-56$ & 260000 & 240000 & 5 & 20 & $3-6$ \\
\hline $440 B$ & $520-590$ & C53-58 & 280000 & 270000 & 3 & 15 & $2-5$ \\
\hline $440 \mathrm{C}^{\prime}$ & $540-620$ & C.55-60 & 285000 & 275000 & 2 & 10 & $1-5$ \\
\hline
\end{tabular}

質を第 6 表に示す。

耐鳋性：Strauss と Talley11)が行った噴霧試験による 耐蝕性と加熱温度の関係を第11図に示す。この種の鋼は $1000^{\circ} \mathrm{F}\left(538^{\circ} \mathrm{C}\right)$ 以上で延伸すると耐蝕性の減少が著し い。またこれらの曲線によると最初の焼入温度は高くな い万がよいことがわかる。第 7 表は $65 \% \mathrm{HNO}_{3}$ 沸膫溶 液による腐蝕試験結果を示すもので，やはり普通の腐蝕 液の場合とは逆に焼入れた材料の方が多く侵される。

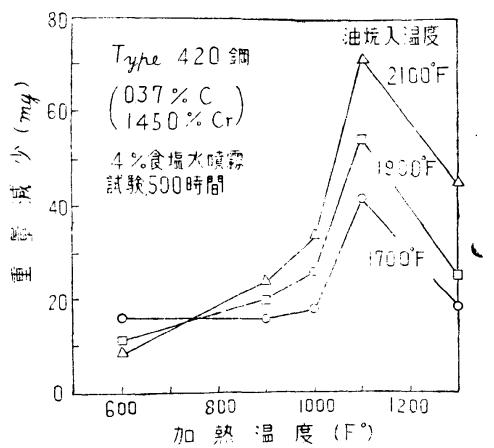

第 11 図 320 鋼 の耐蝕性に及ぼす歪除去加熱の影響

茀 7 表 Type 420,440.A,440C の沸騰 65\% 硝酸 中の腐蝕度

\begin{tabular}{|c|c|c|c|c|}
\hline 鎆種 & 熱 & 処 & $\mid \begin{array}{ll}\text { プリ } \\
\text { 硬 } \\
\text { 度 }\end{array}$ & 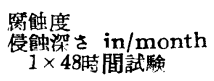 \\
\hline \multirow[t]{2}{*}{420} & $1900^{\circ} \mathrm{F}$ 焼入 & $500^{\circ} \mathrm{F}$ 歪除去 & 514 & 0.0480 \\
\hline & $"$ & $1200^{\circ} \mathrm{F}$ 焼 展 & 248 & 0.0239 \\
\hline \multirow[t]{2}{*}{$440 \mathrm{~A}$} & $1950^{\circ} \mathrm{F}$ 焼入 & $500^{\circ}$ F丕除去 & 524 & 0.0412 \\
\hline & $"$ & $1400^{\circ} \mathrm{F}$ 焼 㞔 & 217 & 0.0081 \\
\hline \multirow[t]{2}{*}{$440 \mathrm{C}$} & $1950^{\circ} \mathrm{F}$ 焼入 & - $500^{\circ} \mathrm{F}$ 丕除去 & 555 & 0.0761 \\
\hline & $"$ & $1400^{\circ} \mathrm{F}$ 焼 民 & 241 & 0.0452 \\
\hline
\end{tabular}


総括

硬化性不銹鋼の用途は増加してきたが，熱処理法の誤 解や鋼種と熱処理法の選択の誤りが原因で破損を来たし た例が見受けられる。鋼整避択に当っては酎蝕性叔よび 機械的諸性質が勢処理によって著しく变ることに注意し なければならない。Type 403,410,414,416,481 のよう な低宸素鋼の機械的性質は必然的にその組成によって変 るからこれらの鋼種を熱処理して狹い範因の機械的性 質を得ようとするときは，このことを忘れてはいけない。 供給された材料が希望する性質を出すか否かを知るには 材料の用途，加工法持よび用いられる輍好理について專 門知識を必要とするのである。

\section{引用交献}

1) S.P.Watkins: The Corrosion Resistance of Free Machining Stainless Steel. Metal Prog. 39, 710 714 (1941)

2) W.Crafts \& J.L. Lamout: Secondary Hardening of Tempered Martensitic Alloy Steel. TP 2439-Metals Technology, Sep. 1948, 1 42
3) I.H. Hollomon \& L.D. Jaffe: Tine-Temperature Relations in Tempering Steel. Trans. AIMME, Iron and Steel Div., 162, 223 249 (1945)

4) R.L. Rick:t, W.F. White, C.S. Walton \& J.C. Butler: Isothermal Transformation, Hardening and Tempering of $12 \%$ Chromium Steel. Trans. ASM, 44, 138 - 175(1952)

5) USPat. 2, 218,973 (Oct.22.1940), 2, 262,690 (Nov.11,1941)

6) J.P.Fraser \& R.S.Treseder:Cracking of High Strength Steels in Hydrogen Selfide Solution. Corrosion, 8, No. 10, 342 350 (1952) Oct.

7) NACE TP-IG Comm. Rep. Field Experience with Cracking of High Strength Steels in Sour Gas and Oil Wells. Corrosion, 8, No. 10, 351 354 (1952) Oct.

8) F.A. Prange: Hydrogen Embrittlement Tests on Various Sheets. Corrosion, 8, No. 10, 355 357 (1952) Oct.

9) C. A. Zapffe \& O.G. Specht : Effect of Composition, Heat Treatment and Cold Work on the Hydrogen Embrittlement of Stainless Steel Wire During Cathodic Pickling. Trans. ASM, 39, 193 212 (1947)

10) H.J.Gough \& I. G. Sopwith : Some Comparative Corrosion Fatigue Teste Employing Two Types of Stressing Action. J. Iron and Steel Inst., 127, 301 335 (1933)

11) I. Strauss \& J.W. Talley : Stainless Steels-Their Heat Treatment and Resistance to Sea-Water Corrosion. Proc. ASTM, Part 2, 24, 217 258 (1924)

\section{学振第 97 委車会機関誌防蝕技術の配布走受ける方法}

本誌は日本学術振興会[腐蝕防止第97委員会䦭係]維持会買飞配布するとと を立前として，引続さ会員を募集中でありむす。申迅むれれ会員は維持会に 䦭する従来の規定を準用し，「腐蝕防止第 97 委員会と指定されれ学振維持会 貝」となられるわけであり，てれに閔する規定は下記の通りでありむす。

\section{学振腐蝕防止第97委員会関係維持会貝規定}

I 会員は普通会負と特别会貝とに分ける。

II 普通会負は團体及び個人を対象とし，会費は1 日《付さ年額 1,000 可と する。

普通会負の受ける特典は次りをおりである。

1. 1 口飞付さ防蝕技街（1 年 6 册刊行）每号 1 部の配布を受ける。

2. 本委員会主催の講習会々費等の割引を受ける。

特別会員は團体を対象とし，会費は半口飞. 付气年額10,000内とする（半

口以上で特別会貝として入会でさすす)

特別会貝の受ける特典は次のとおりである。

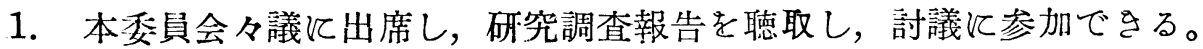

2. 半口飞付さ防蝕技術（1 年 6 册刊行）每号 3 部の配布を受ける。

3. 本委員会主催の講習会々費の割引を受ける 